\title{
College Students' English and American Literature Teaching Under the Humanistic Concept
}

\author{
Liwei $\mathrm{Yu}$ \\ Foreign Language Teaching Department, Inner Mongolia University for the Nationalities, \\ Tongliao,028000, China
}

Key words: Humanistic ideas, College students, British and American literature

\begin{abstract}
British and American literature teaching is colleges and universities in our country, it is very important in the English class and the humanities class professional course, can through to the British and American literature appreciation to promote students' aesthetic ability, and make students under the influence of infiltration, develop a positive and healthy mental quality. But British and American literature teaching in China's colleges and universities under the influence of all kinds of reasons there are some problems, the students' learning enthusiasm, initiative and creativity are relatively low, the actual effect of British and American literature teaching cannot effectively. So, at this stage, based on humanistic ideas, should strengthen to the attention of the British and American literature teaching, to penetrate humanistic idea into the teaching practice, with students as the main body of teaching activities, as well as improve the teaching effect to strengthen the training of students 'humanistic spirit.
\end{abstract}

\section{Introduction}

British and American literature are for English majors in our university, one of the most important lessons in over the years by the extensive attention of the organization of education of colleges and universities, the students' language basic skill and the cultivation of humanistic quality plays an extremely important role. But under the influence of literary characteristics, the role of literary education to cultivate the students' comprehensive qualities of students are usually subtle, cannot produce quick effect, to a certain extent, led to a large number of students under the influence of social thoughts in the current pragmatism, attaching too much importance to all kinds of license certificate, and neglected for British and American literature study, the effect of classroom teaching is affected by the serious. In the context of globalization, therefore, based on humanistic ideas to reform British and American literature teaching, make it play a role of education effectively, has become the current education focus on the problem.

\section{Humanistic philosophy}

Humanistic concept simple said is humanist, takes the concept of man as the main activities, stress the harmony between people exchanges, mutual respect, understanding and support. Humanistic concept in Chinese and western society has a long history, as early as the ancient Greeks had philosophers put forward "man is the measure of everything" academic point of view. In the spring and autumn period of the pipe in the pipe also said ", the overlord of the beginning, also is with the person this ", these are the typical representative of humanistic thoughts. And the humanistic thoughts of research in modern social psychology thoughts rise up in the middle of the last century, the United States, committed to the human nature, the content of the experience and self-realization, and after a systematic study from the natural human nature and put forward the idea to the theory of self-realization, eventually to build a set of comprehensive system of humanistic teaching idea, Rogers's humanism learning theory is one of the most typical representative of the cause of education reform in our country have the extremely important influence. 


\section{The reason of British and American literature teaching in modern society the lack of the idea}

\section{The influence of the traditional teaching mode in our country}

Traditional teaching concept of modern education in our country has a deep-rooted influence. Our traditional teaching thought on "teacher center" and "main" two ideas as the core, not only to the students as an independent individual should play their roles in teaching practice to ignore this problem, will also be talented person's raise firmly limit in knowledge teaching, neglect the cultivation and comprehensive development of students' comprehensive quality. Traditional teaching mode to teaching as the center of the whole teaching, students in the process, completely lost the subject position, put the cart before the horse, the relationship between teaching and learning not only restrict the development of innovative teaching ideas, also seriously affected the students' learning initiative and self-consciousness, unfavorable to students' future development.

\section{The deepening of the market economy development has a corresponding negative impact on} teaching activities

In recent years, with the deepening development of China's socialist market economy, college enrollment expansion and increasingly fierce competition for jobs, and made an impact on the basic conception of personnel training in colleges and universities, to some extent, lead to the "market-oriented" education thought has become the mainstream in the talent cultivation thoughts, are increasingly strengthen college education industrialization and marketization trend, although to a certain extent, help to ease social contradictions, provides a large number of practical talents for the society, but it is undeniable that this teaching mode makes manifest utilitarian and secular trends of university education, students lose interest in learning in poor practical subject, is not conducive to the all-round development of students.

\section{Students' various abilities}

In the current teaching practice of college English and American literature in our country, there are also some of the young teachers is affected by the educational reform thought more emphasis on humanistic concept, introduced in the teaching practice, hope to be able to take this to mobilize students' subjective initiative, to create a good environment for students' self-actualization. However, because the student has been affected by the traditional education ideas, their comprehensive quality is low, ability is insufficient, is extremely narrow to humanities knowledge, their own knowledge structure is not reasonable, etc., severely limits the development of the teaching effect, make the teachers' teaching reform is difficult to play the proper value.

\section{The literature class construction of "four generations" teaching mode under the humanistic concept}

Aiming at the disadvantages of traditional teaching mode, combined with humanistic concept, related education department officially launched after joint exploration and practice of "four generations" teaching model, not only can improve the current status of British and American literature teaching, also can cultivate the students' humanities cultivated manners, promote the all-round development of students, has a very high practical value. First of all, to learning and teaching, emphasizing should improve the students' autonomous learning awareness and ability of independent learning. This view is really has certain significance and value of learning must be the student of subjective thought consciously, students can according to their own needs to arrange learning situations, find problems and solve the problem, study effect will also get corresponding improvement. Second, with the generation, the ability to learn follows up. Human-oriented concept in the teaching thought generally emphasis on cultivating students' innovative and practical aspects of the comprehensive quality, hope that students can gradually by learning to raise their ability of knowledge acquisition, access to information and communication cooperation ability, only teachers in the teaching with the generation, create more opportunities to participate in the classroom for students, students' ability of these aspects will be the corresponding reinforcement. Again, in the generation of a single, that is, through the comprehensive teaching way of exploring the non-computer majors instead of the traditional single teaching. That is to say, the teacher in the 
classroom instruction can watch the literariness of film and television works with students, according to the extracurricular reading, reading a lot of the English original conditions appropriate to write comments, arouse students' interest in English and American literature teaching, and make students in the comment on writing, deep thinking, to raise their cultural accomplishment and ideology. Finally, one generation said that attaches great importance to moral education. Humanism education idea that education should focus on the comprehensive development of educates, therefore the teaching emphasis should be placed in the form of the good relationship between teachers and students and teachers the right attitude. That is to say, in order to promote the all-round development of students, teachers should guide students in the teaching practice to explore and comprehension, rather than lecturing. "Teach than teaching", attach importance to students in the education practice of quality education is of great significance.

\section{Humanistic concept of British and American literature teaching optimization measures}

Rogers education idea of "student-centered" humanistic point of view, has extremely profound interpretation to the education teaching, some of the more classic, such as how to develop the "whole person" in the education practice of the education purpose, to "real problem" as the key content of teaching concept, with "independent evaluation" as the core concept of teaching evaluation, and to "student centered" view of the fundamental teaching process and so on, with the essence of education and the basic law of development not only corresponds to, also be able to keep up with the trend of the teaching of modern society, to our country market economy under the influence of British and American literature teaching reform have considerable revelatory effect. Therefore, based on humanistic ideas, we can take the following optimization measures of British and American literature teaching reform.

\section{Set teaching target, stimulate students' interest in learning}

With the further development of China's economic and social, under the influence of socialist market economy gradually thriving "instrumental" and "utility" of foreign language teaching for foreign language talents cultivation has brought great negative impact. Therefore, in the quality education gradually thriving in today's society, how to reverse the foreign language teaching is to ignore the embarrassing situation of humanistic quality education to the student, how to through the foreign language teaching to further arouse the enthusiasm of students learning English and American literature course, has gradually developed into a foreign language education focus on the problem. Concept of humanistic education will develop "whole person" as the basic teaching goal, to develop positive and comprehensive talents with certain innovation consciousness as the main purpose of education. The education purpose in nature reflected in the traditional teaching mode of talent to a single knowledge and intelligence training reform, pay attention to the all-round development of people, especially pay attention to the development of human emotion, spirit and values, etc. Based on this view, teachers of English and American literature in the education practice should cultivate the students' interest in learning, improve students' humane quality as the basic purpose of teaching, and give full play to the British and American literature education to students the importance of humanistic quality education, to create the corresponding condition for promoting students all-round development.

\section{Reform the teaching content, strengthen the contact of student life}

Rogers's humanism education thought will be a real problem as the main teaching content, to let all the students in different stages of education, can learn by class come into contact with the real problems is closely related to its survival and development, and enhance its ability to solve practical problems of life. The teaching idea of humanistic education concept requires teachers in teaching must adhere to the principle of their aptitude, and combined with the different types of students' learning needs, continuously optimize the teaching content, to maximize stimulate students' interest in learning, enhance the level of the students' knowledge. On the one hand, the choice of teaching content should be followed by Jane to numerous basic cognitive law of, from easy to difficult, carefully selected some with rich era characteristics, to reflect the current social teaching knowledge of the most advanced culture thought, let the students contact more modern when British and 
American literature classic, strengthen the cognition of modern and contemporary society. It is also need to pay attention to the choice of, on the other hand, should be able to keep up with the students' psychological accept ability, the choice of teaching content should not only has a certain meaning of language education, and to show the specific social significance and humanistic education thought, thus effectively inspire students through teaching practice positive thinking similar social phenomenon, help them form the correct outlook on life and values.

\section{Explore diversified teaching forms, create a good learning atmosphere}

Humanistic teaching concept of the teaching process students as the center of teaching activities, attach importance to student's main body status, hope to change the teacher's role in the education reform, the teachers as a teaching guide and helper for students to create a good learning environment, provides a wealth of teaching resources, and promote the all-round development of students. Based on this, the British and American literature class teaching practice, teachers can make some appropriate high quality courseware, strengthen the teaching of novelty and interesting, effectively relieve the contradictions of classroom teaching, strong students' study pressure. It Can also be a reasonable selection of some of the higher education value of $C D$, video and other multimedia auxiliary teaching means modernization, to further strengthen the teaching content, in a more intuitive way to stimulate students' interest in literature study first, prompting the students in the process of autonomous learning can produce works with resonance, improve the teaching effect. Joint school teachers can also be other relevant departments organize some poetry reading, literature plays, such as extracurricular activities, students in extra-curricular contests to deepen the understanding of British and American literature, then eliminate the strange and fear psychology of British and American literature teaching, make their experience to the literature study interest, and to strengthen their own learning, promote students comprehensive development.

\section{To strengthen the attention of the teaching evaluation, cultivate students' autonomous learning consciousness}

In the humanistic education idea that teaching evaluation should be independent evaluation as the core, the idea that the essence of the corresponding link of teaching evaluation, to stimulate students' learning responsibility consciousness, thus enabling students to more actively involved in the study life. Therefore, the teacher in the education practice should be actively developed students self-evaluation and mutual way of teaching evaluation, lets the student in the summary and reflection on the more profound know themselves, then change themselves, to improve myself. At the same time, the teaching evaluation as one of the most important part of modern education, it is also an important bridge to strengthen the emotional communication between teachers and students. In British and American literature class, the teacher, a good student who gave a positive evaluation of performance can urge and spur the students to play a role. To sum up, the strengthening of the evaluation of the whole teaching effect have an important impact, teachers should strengthen the evaluation problems in teaching, perfecting the evaluation system, all-round develop multiple evaluation standard, to help and guide students to reasonable control the learning process itself, let the student to obtain the joy of success, confidence in the enhanced learning at the same time, to be more high enthusiasm into the next phase of the study.

\section{Conclusion}

To sum up, under the concept of people-oriented, with students as the center of teaching activity to proper reform, British and American literature education not only helps further improve the teaching level, create conditions for the all-round development of students, give full play to the British and American literature's important role in the humanities education, also can improve students' ideological and moral quality and cultural accomplishment, deepen students' understanding of all kinds of social phenomenon, to form the correct outlook on life and values, to lay a solid foundation for its future development. 


\section{References}

[1] Wang Zhe. The literature teaching of humanism education and the British and American. Journal of continuing education research,2012(8):163-165.

[2] Li Chunning. Introduced in British and American literature teaching concept of humanistic education. Journal of Hebei normal university (education science edition),2010,12(6):110-113.

[3] Li Chunning, Li Wei. Humanistic learning view of British and American literature teaching enlightenment. Chinese science and education innovation Tribune,2010(4):133.

[4] Chen Xi. British and American cultural differences on English and American literature review analysis. The influence of campus English (middle),2014(5):110-110.

[5] Zhang Lijuan. The British and American literature teaching under the guidance of humanistic theory. Journal of Jiamusi institute of education,2012(9):99. 